\title{
Analysis of Utilization of Traditional Medicine for the Treatment of Malaria among Rural Farmers in Abia State, Nigeria
}

\author{
Mbah, G.O.*; Ekweanya, N.M.
}

\author{
Department of Rural Sociology and Extension Michael Okpara University of Agriculture, Umudike, Nigeria \\ Corresponding Author*
}

\begin{abstract}
The study investigated the level of utilization of traditional medicine for treatment of malaria among rural households in Abia State, Nigeria. Specifically, the study described socio -economic characteristics of the respondents; ascertain the extent of utilization of traditional medicine among the respondents and determine the factors influencing level of usage of traditional medicine in the area. Data for the study were collected from (180) respondents using structured questionnaire and analyzed using both descriptive and inferential statistics. The result showed that $55.0 \%$ of the respondents were males, average age of 58.45 years, $81.2 \%$ were married and $45.0 \%$ had secondary education. The study further revealed that respondents had high access to medicinal plants from market (mean $=2.35$ ) and traditional medical practitioners (mean $=2.36)$. Tobit regression result showed that coefficient of age, years of education, income and farming experience influenced access to traditional medicine at $1 \%$ probability level. The study concluded that there was moderate utilization of traditional medicine for treatment of malaria in the study area, and recommended ensuring appropriate information on traditional medicine efficacy for effective utilization by the farmers in the study area.
\end{abstract}

Keywords-Utilization, Traditional Medicine and Rural Farmers.

\section{INTRODUCTION}

Agriculture is the mainstay of the Nigerian economy. It employs about two-thirds of the country's total labour force, contributing about $45 \%$ of GDP and providing the means of livelihood for over $70 \%$ of the population (IFAD, 2009). Agriculture is also a major source of raw materials for agro-allied industries (Oboh et al, 2009). It is carried out mainly in the rural areas by rural farmers who play several roles in an agrarian country like Nigeria, given their capacity for job creation and local food production (AsensoOkyere, 2011)

About $90 \%$ of Nigearia's food is produced by small-scale farmers who cultivate small plots of land and depend mostly on rainfed agriculture rather than on irrigation systems. Agricultural development provides suitable conditions for breeding of anopheles mosquitoes which is the vector of plasmodium parasite (Asenso-Okyere,et al 2011). Agriculture and health being bi-directionally linked, perpetuate poverty in rural areas, where up to $80 \%$ of the population are farmers and live below the poverty line. Food, social services and infrastructure are limited to the population (IFAD, 2009), they tend to be vulnerable to malnutrition, illiteracy and poor health condition especially in the absence of modern, adequate and functional primary health care facilities. In Nigeria, malaria is endemic and it occurs throughout the year. Traditional medicine is the sum of the total of the knowledge, skills and practices based on the theories, beliefs and experiences indigenous to different cultures, whether explicable or not, used in the maintenance of the health, as well as to prevent diagnose, improve or treat physical and mental illness (WHO, 2000). Traditional knowledge plays a significant role in life style of the members of the local communities and hence an essential resource for any human development process. They form the basis of decisions pertaining to food security, human and animal health, education, natural resources management and other vital activities

According to Federal Ministry of Health (2005), there are over 100 people at risk of malaria. Nigeria has the third highest rate of maternal mortality in the world (1100 per 100,000) after Sudan and Democratic Republic of Congo. The major cause of this being ill-health of which malaria scourge is distinguished (USAID, 2008) Attitude toward malaria as a disease is important in understanding healthseeking behaviour and utilization of preventive methods. 
Many rural people do not trust Western method medicine, preferring instead to use traditional ways which is an alternative or non-conventional mode of treatment involving the use of herbs in a non-orthodox manner, as well as the process of consulting herbalists, mediums, priests, witchdoctors, medicine men and various local deities (Mafimisebi and Oguntade, 2010). Good knowledge, attitude and practices of any public health disease by individuals and communities seems necessary if effective treatment and preventive measures are to be realistic (Iwueze et. al., 2013). These treatments are usually incorrect or sub-optimal since they are most times administered without proper diagnos is (Okeoluwapo et. al., 2008).

Malaria is usually first treated at home with herbal teas and baths prepared with neem, pawpaw, guava, and eucalyptus leaves. Analysis of "what respondents will do first" during malaria attack showed that only 35.5 percent of respondents will use synthetic antimalarial drugs, 13.4 percent will use local herbs, while 27.3 percent will go to the hospital, and 18.2 percent will just pray (Asenso-Okyere et. al.,2009). Utilization of traditional medicine is complex and varies among member states. It is important to take into consideration the utilization pattern of a location in other to ensure that the information developed will be effective and appropriate to the specific country location and their culture . Reliance on herbs as the first treatment action for malaria was also noted in South-east Nigeria upon which this paper intends to ascertain the extent of utilization of Traditional Medicine for the Treatment of Malaria among

Rural Farmers in Abia State through the following specific objectives

1 ascertain the extent of utilization of traditional medicine among the respondents,

2 identify the problems associated with traditional medicine practice and utilization

$\mathrm{HO}_{1}$ : There is a significant relationship between some socio-economic characteristics of the respondents and utilization of traditional medicine.

$\mathrm{HO}_{2}$ : There is no significant difference between farmers' level of access and utilization of traditional medicine

\section{METHODOLOGY}

The study was conducted in Abia State, Nigeria. Abia State is located within latitudes $400 \mathrm{~N}-470 \mathrm{~N}$ of equator and longitude $70-80 \mathrm{E}$ of the Greenwich Meridian NRCRI, 2010). The state has a total land area of about 5,410sq kilometers, with a human population of about 2,881,380 (NPC, 2017). Abia State shares a common boundaries with
Rivers State in the South, Imo in the West, Ebonyi and Enugu States in the North and Akwa Ibom and Cross River States in the East. Abia State is made up of 17 Local Government Areas (LGAs) and three agricultural zones namely Aba, Ohafia and Umuahia. Most people especially the rural dwellers are engaged in subsistence farming, producing such arable crops as cassava, yam, cocoyam, maize, vegetables, melon, banana/plantain sweet potatoes and rice. The study was conducted in Bende and Ohafia Local Government Area in Abia State. Both LGAs lies within approximately latitudes 5'34" North of the equator and longitudes 7'38" East of the Greenwich Meridian. It covers an area of about $304.45 \mathrm{sqKm}$ with 192,111 people (FRN, 2007; NPC, 2006), among which 128,074 people are females and 64,034 are males, according to the NPC state and Local Government Census figure. The major occupation of this people is farming, with other occupations like civil services, and businesses. It is a low-land with a heavy rainfall of about $2,400 \mathrm{~mm}$ between May and October, which favours agricultural activities. These Local Government Area is blessed with several inland water channels and seasonal run-offs. It has a tropical climate with average temperature of $7.20 \mathrm{c}$ from January to April and over 21.10c from September to December. The great variety of plants in L.G.A reflects its rich soil and topography. Major food and cash crops produced include cassava, yam, plantain and oil palm. Other economic activities engaged by the people include, handcrafts and petty businesses. (Imo Bulletin, 2006).

Multi-stage random sampling technique was used in selecting 180 (one hundred and eighty) respondents in the study area. In the first stage, two local government areas were purposively selected from Abia State, namely Bende, and Ohafia. In the second stage, one autonomous community was selected from each of the Local Government Area. In the third stage, two (2) villages were randomly selected from each of the selected autonomous communities making a total of eight (6) villages. In the third stage, 30 respondents were randomly selected from the villages selected. This will give a sum total of eighty (180) respondents which made up the sample size for the study, Both descriptive and inferential statistics was used to analyze the data collected for the study

\section{MODEL SPECIFICATION}

The model for the mean decision used in this work is specified thus:

Where,

$$
\bar{X}=\frac{\sum \mathrm{fx}}{\mathrm{n}}
$$

www.ijeab.com

Page | 375 
$\sum=$ Summation of the frequencies

$\mathrm{Xs}=$ As signed scores to different categories

$\mathrm{n}=$ number of sample

$\overline{\mathrm{X}}=$ Arithmetic mean

Hypothesis 1 and 2 were analyzed using Tobit regression estimates which is specified thus:

$\mathrm{Y}=\mathrm{f}\left(\mathrm{X}_{1}, \mathrm{X}_{2}, \mathrm{X}_{3}, \mathrm{X}_{4}, \mathrm{X}_{5}, \mathrm{X}_{6}, \mathrm{X}_{7} \ldots \mathrm{Xn}, \mathrm{e}\right)$

Tobith model expressed thus;

$1_{\mathrm{i}}=\mathrm{B}^{\mathrm{T}} \mathrm{X}+\mathrm{e}$

$Y_{i}=$ if $1=T$

Where,

$\mathrm{Y}_{\mathrm{i}}=$ represent a limited dependent variables which simultaneously measures the level of access and utilization of traditional medicine.
$\mathrm{T}=$ observed threshold

$1^{\mathrm{x}}=$ the underlying content variables indexing the levels of access and utilization

$\mathrm{Xi}=$ the vectors of independent variables

$\mathrm{X} 1$ = Age of respondents (years)

$\mathrm{X} 2=$ marital status $($ married $=1$, single $=0$ )

$\mathrm{X} 3$ = level of education (number of years spent in school)

$\mathrm{X}_{4}=$ Gender $($ male $=1$, female $=0$ )

$\mathrm{X}_{5}=$ Occupation

$\mathrm{X}_{6}=$ Household size (number of persons)

$\mathrm{X}_{7}=$ Income (Naira)

\subsection{LEVEL OF UTILIZATION OF TRADITIONAL MEDICINE}

Table.1. 1: Distribution of the respondents based on their level of utilization of medicinal medicine

\begin{tabular}{|c|c|c|c|c|}
\hline Level of utilization & Sum & Std Dv & Mean & Rank \\
\hline Drinking neem water squeezed out & 157.0015 & 0.77040 & 1.96 & $5^{\text {th }}$ \\
\hline From the leaves to cure malaria. & & & & \\
\hline $\begin{array}{l}\text { Steam bathing and inhalation of boiled leaves (roots) bark concoction } \\
\text { from roots and leaves to cure malaria. }\end{array}$ & 148 & 0.74799 & 1.85 & $6^{\text {th }}$ \\
\hline Drinking of boiled concoction from roots and leaves to cure malaria. & 197 & 0.54988 & 2.46 & $1^{\text {st }}$ \\
\hline Drinking of tree bark, roots and alcohol concoction to cure malaria. & 164 & 0.78276 & 2.10 & $4^{\text {th }}$ \\
\hline Drinking of boiled concoction made from unripe fruits to cure malaria. & 185 & 0.68610 & 2.31 & $2^{\text {nd }}$ \\
\hline Rubbing of traditional lotions and concoctions to cure malaria. & 174 & 0.80779 & 2.18 & $3^{\text {rd }}$ \\
\hline Combining medical therapy with traditional medicine. & 86 & 0.30914 & 1.08 & $7^{\text {th }}$ \\
\hline Total mean & & & $\mathbf{1 3 . 9 4}$ & \\
\hline Grand mean & & & 2.00 & \\
\hline Benchmark mean & & & 2.00 & \\
\hline
\end{tabular}

Source: Field survey, 2018.

The result Table 1.1 showed distribution of the respondents based on their level of utilization of medicinal medicine in the study area. Generally, the respondents had high level of utilization of medicinal plants in the study area. The respondents highly utilized medicinal plant in the areas of drinking of boiled concoction from roots and leaves to cure malaria (mean $=2.46$ ), drinking of boiled concoction made from unripe fruits to cure malaria (mean $=2.31$ ), rubbing of traditional lotions and concoctions to cure malaria $($ mean $=$ 2.18), drinking of tree bark, and roots and alcohol concoction to cure malaria (mean $=2.10$ ).
The result is plausible owing to the fact that traditional medicine is accessible, affordable, culturally acceptable, socially sanctioned and easy to prepare with little or no side effects. Most rural households prefer traditional medicine to the exorbitantly priced conventional health care services. Adesina (2014) and Alarm (2011) were of the notion that $75-80 \%$ of the population in Africa uses traditional medicine for their needs.

\subsection{PROBLEMS ASSOCIATED WITH} TRADITIONAL MEDICINE

Table.1.2: Distribution of the respondents based on the problems associated with traditional medicine

\begin{tabular}{lll}
\hline Problems & Frequency & Percentages \\
\hline Poor and inadequate medical facilities. & 53 & 66.2 \\
Limited access and use of these medicines. & 37 & 46.2 \\
Poor quality assurance & 25 & 31.2 \\
There are very few practitioners in area. & 55 & 68.8
\end{tabular}


The practitioner is not easily accessible.

There are very few healers in attendance.

The drugs have no dosage

Drugs are not usually available.

There is no provision from practitioners to visit very sick patient at 41 home.

High transport cost to traditional healers.

Traditional healers are not well trained or skilled

Lack of knowledge and ignorance

Traditional healers are not well trained/ skilled.

Unhygienic nature of traditional medicine.

At times they are out of reach of patients.
$35 \quad 43.8$

$54 \quad 67.5$

$52 \quad 65.0$

$28 \quad 35.0$

$41 \quad 51.2$

$51-63.8$

$42 \quad 52.5$

$43-53.8$

$38 \quad 47.5$

$44 \quad 55.0$

$37 \quad 46.2$
Source: Field survey, 2018

*Multiple responses recorded

Table 1.2 showed the distribution of the respondents based on the problems associated with traditional medicine in the study area. The result showed that the respondents perceived some challenges as sociated with medicinal plants. These challenges were that there are very few practitioners in area $(68.8 \%)$, very few healers in attendance $(67.5 \%)$, poor and inadequate medical facilities $(66.2 \%)$, drugs have no dosage $(65.3 \%)$, high transport cost to traditional healers $(63.2 \%)$, unhygienic nature of traditional medicine $(55.0 \%)$, lack of knowledge and ignorance (53.8\%), traditional healers are not well trained or skilled (52.5\%) among others.

Hypothesis

Table.1.3: Regression estimates of the relationship between socioeconomic characteristics of the respondents and level of utilization of medicinal plants in the study area

\begin{tabular}{lllll}
\hline Variables & Parameters & Estimate & Std. Error & T - value \\
\hline ge & $X_{1}$ & .026 & .025 & $2.104^{* *}$ \\
Gender & $X_{2}$ & 1.553 & .499 & $9.701^{* * *}$ \\
Marital & $X_{3}$ & -.331 & .888 & .139 \\
Years of education & $X_{4}$ & .170 & .133 & 1.634 \\
Household size & $X_{5}$ & .035 & .121 & .085 \\
Farm size & $X_{6}$ & .070 & .188 & .139 \\
Occupation & $X_{7}$ & 1.659 & .811 & $4.187^{* * *}$ \\
Income & $X_{8}$ & $3.022 \mathrm{E}-7$ & .000 & $6.014^{* * *}$ \\
Farming experience & $X_{9}$ & .030 & .025 & 1.440 \\
\hline Pseudo R-Square & & 0.573 & & \\
-2 Log Likelihood & & 264.103 & & \\
Chi-Square & $617.663^{* * *}$ & & \\
\hline
\end{tabular}

\section{Source: Field survey, 2018}

Keys: *** indicates significance at $1 \%$

Table 1.2 showed Tobit regression estimate of the relationship between selected socioeconomic characteristics and the utilization of medicinal plants in the study area. The Pseudo R-Square of 0.573 indicated that $57.3 \%$ of the variations in the dependent variable were accounted for while others were due to error. The chi-square value was statistically significant at $1 \%$ level of probability indicating the Tobit regression line of best fit. The coefficients of age, gender, occupation and income positively influenced the intensity of utilization of medicinal plants in the study area. Furthermore, the coefficient of age was statistically significant at $1 \%$ level of probability. This result implies the older person will have high intensity and probability of utilization of medicinal plants. The coefficient of gender was statistically significant at $1 \%$ level of probability. The result implies that male respondents had more intensity of 
utilization of medicinal plants than their female counterparts in the study area.The coefficient of occupation was statistically significant at $1 \%$ level of probability. The result implies that farmers had more intensity of utilization of medicinal plants than non farmers' counterparts in the study area. This may be attributed to the fact farmers are more familiar with these medicinal plants than non farmers.
The study therefore rejected the null hypothesis which stated that there is no significant relationship between some socio-economic characteristics of the respondents and utilization of traditional medicine and concluded otherwise. Hypothesis 2

Table.1:4 Z-test comparative analysis of the difference in the access and utilization ofmedicinal plants

\begin{tabular}{llllll}
\hline Variables & Mean & Std. Deviation & Std. Error Mean & Df & Z - Test \\
\hline Access & 1.9625 & .27759 & .03104 & & \\
Use & 1.9911 & .24517 & .02741 & 79 & 0.900 \\
Access - Use & -.02857 & .28408 & .03176 & 79 \\
\hline
\end{tabular}

\section{*No significant difference}

The result in table 1.4. showed Z-test of the difference in the levels of access and utilization of traditional medicine in the study area. The result showed the mean value of access 1.9625 and mean utilization value of 1.9911 with mean difference of 0.02857 . The difference obtained implied that there is no statistically significant difference in the levels of access and utilization of medicinal plants in the study area.

\section{CONCLUSION AND RECOMMENDATIONS}

The study concluded that there was moderate high utilization of traditional medicine in the treatment of malaria in the study area. It is therefore important to ensure that the appropriate information is made available to the consumers to enable effective utilization which entails maximizing the benefit of traditional medicine while minimizing the risks Production of traditional malaria drug with labeled instruction, dosage and expiry date, so as to ensure adequate utilization. Traditional doctors should ensure that the drugs are produced in a hygienic environment. Women and youths should be encouraged to utilize traditional medicine in the treatment of malaria in the study area.

\section{REFERENCES}

[1] Adesina, S.K. (2014). Traditional medicine care in Nigeria: online Nigeria daily news. Accessed on: 29 February 2016 at www.onlinenigeria.com

[2] Asenso-Okyere, K. Asante, F. A., Tarekegn, J., \& Andam, K.S (2009). The Linkages between agriculture and malaria: Issues for policy, research, and capacity strengthening. Knowledge, Capacity, and Innovation Division. Washington, D.C.: International Food Policy Res earch Institute.
[3] Asenso-Okyere, K., Kwaw A., Aragon, C., Thangata, P., \& Mekonnen, D. A. (2010). HIV and AIDS and farm labour productivity: A review of recent evidence in Africa.Journal of Development and Agricultural Economics, 2(12): 406-41.

[4] Iwueze, M. O., Ezugbo-Nwobi, I. K., Umeanaeto, P. U., Egbuche, C. M. \&Anaso, C. I. (2013). Knowledge, attitude and management practices on malaria: A case study of Amansea, Awka North Local Government Area of Anambra State, Nigeria. The Bio scientist, 1(1): $32-38$.

[5] Mafimisebi, T. E., \& Oguntade, A. E. (2010). Preparation and use of plant medicines for farmers' health in Southwest Nigeria: socio-cultural, magicoreligious and economic aspects Journal of Ethno biology and Ethno medicine, 6 (1):1746-4269

[6] National Population Commission (2006). Population figure Federal Republic of Nigeria. http.www.npc.gov

[7] Okeoluwapo, O.A., Falade, C.O., Bamgboye, E.A., Oduala, A.M. \&Kale, O.O. (2008). Assessment of improvement guideline to improve home management of malaria in children in rural south-west Nigeria. Journal of BioMed Central, 7(24): 1475-1587

[8] World Health Organization (2006) General Guidelines for methodologies in research and evaluation of traditional medicine, Geneva, Switzerland. 